\title{
Ten years later: A Comparative perspective on HRM Issues in Foreign-Affiliated firms in CEE (Case of Slovakia) ${ }^{*}$
}

\author{
Sonia Ferencikova ${ }^{* *}$
}

This paper is based on a 1999 survey of the largest foreign investors in the Slovak Republic. The main objective of the study is to measure the impact of foreign investors' human resource management practices on local companies and their environment in a more detailed way, to identify key problems in the human resource function in FDI-invested companies in Slovakia, and to describe the strategies that companies use to handle these problems.

Die Grundlage für diesen Artikel bildet eine Übersicht über die größten Auslandsinvestoren in der Slowakischen Republik. Der Hauptgegenstand der Studie besteht in einer Messung des Einflusses, den die verschiedenen Formen des Humankapitalmanagement der Auslandsinvestoren auf lokale Unternehmen und deren Umfeld ausübt. Es geht um eine Identifizierung der Schlüsselprobleme des Humankapitalmanagement in Unternehmen mit direkter ausländischer Beteiligung in der Slowakei und um eine Beschreibung der Strategien, die Unternehmen anwenden um diese Probleme zu lösen.

\footnotetext{
* manuscript received: 16.11.1999, accepted: 23.08.2000;
}

This research was undertaken with support from the European Union's Phare ACE Programme 1997. The content of the article is the sole responsibility of the author and it in no ways represents the views of the Commission or its services.

** Sonia Ferencikova, born 1960, Associate Professor in International Business, University of Economics, Bratislava, Department of International Business. 


\section{Introduction}

This paper is based on a 1999 survey of the largest foreign investors in the Slovak Republic. It is a follow-up survey to one done in 1998. The objective of the first survey was to identify internal and external change in FDI firms and to measure the impact of FDI on the restructuring of Slovak companies (see Ferencikova, 1998). According to the results of the first study, implementation of modern management know-how and improvements in the quality of the labor force through training and education were both considered among the positive impacts of foreign investors on local companies and on the economy as a whole. The main objective of the second study is to measure the impact of foreign investors' human resource management practices on local companies and their environment in a more detailed way, to identify key problems in the human resource function in FDI-invested companies in Slovakia, and to describe the strategies that companies use to handle these problems.

\section{Background of the study and method used}

Conventional wisdom holds that FDI-invested companies in transitional economies are mostly successful in comparison to local companies due to several reasons: new technologies, secured foreign market access through corporate networks, and implementation of new marketing and management know-how. Many foreign managers from companies operating in Central Europe underline that the local labor force--its flexibility, education and cost--is one of the most important success factors in this region. They usually highlight that new methods in HRM known from Western countries are very effective here, although sometimes they have to be adjusted to local conditions to get satisfactory results. The goal of this research is to find the answer to this question: Can local companies successfully adopt and adapt the human resource practices of foreign-invested firms? Could local employees become drivers of change? There is also another, practical reason for concentrating on the HRM function in FDI-invested companies: in the previous survey, it was necessary to overcome companies' resistance to share data about revenues, profit, export sales, suppliers etc. In comparison, these same companies were much more willing to share information on employees and human resource practices.

In Slovakia, no similar study of this type was ever done. The reason is the short history of FDI in this country (only since Velvet Revolution in 1989), the complicated way of obtaining and updating related database (there is no governmental agency, office, ministry or bank having complete list of FDIinvested companies in the country) and the resistance of companies to share the data and information about their business. No similar study was found by the author in any European transitional country. The reasons might be the same: short history, no reliable database and data available for researchers. HR studies 
in this region are mostly done by foreign consulting companies with a specialized focus (e.g. compensation and benefits).

However, there are many articles about the role of FDI in transitional economies that mention also the impact on local human resources. The most common are case studies of enterprises with FDI: they usually describe the changes, conflicts and results after the entry of a foreign investor into the previously state-owned company and deal also more or less with changes and conflicts in HR area (see for example Fogel, 1995, pp. 71 - 93, Oddou, Mendenhall, 1998, pp. 197 - 210). There are also available more comprehensive materials focused on people in transition (see for example World Bank, 1996, pp. 66 - 84, 123 - 131), evaluation of local labor force in several transitional countries (see for example World Competitiveness Yearbook, 1998) or area-focused studies (for example analysis of special labor force skills in transitional countries in Business Central Europe, 1999, pp. 45 - 52).

The 1999 country-focused survey, the first of its type in Slovakia, was conceived rather broadly in order to get as much information as possible about HR issues in FDI-invested companies. It covered the following areas: (1) basic information about companies from an HR perspective, such as type and origin of company, investment in HR development, average age of employees, average pay, number of local managers, number of expatriates, localization, and postings of local managers in regional or corporate headquarters; (2) information about specific HR issues, such as sourcing, training and development, performance appraisal, and compensation; key HR challenges with respect to local employees and strategies used to address these challenges; and (3) assessment of the contribution of foreign investor's know-how in HRM to the restructuring of local companies, including numbers on productivity growth and the opinions of local managers about the change brought by foreign investors and their impact on productivity growth. The questionnaire contained 32 questions divided into the three above-mentioned sections.

As the last step of the research, some hypothesis tests were done to determine if there is a correlation between productivity growth in FDI-invested companies led by new HRM methods and other factors, such as type of company, origin of foreign investor, major business of foreign investor, and number of expatriates at the beginning of company's operation.

The questionnaire format was used for all companies with foreign capital investment exceeding the SK 10 million (about US \$250,000). According to the database provided by the National Bank of Slovakia in March 1999, there were 291 such companies. Despite the fact that there are thousands of FDI-invested companies in Slovakia, these 291 firms make up 90\% of all foreign investment when measured in dollar volume. The assumption was that the role and the experience of the largest investors would have much higher explanatory power than that of small investors, most of whom invested the amount up to SK 
100,000 (US \$2,500). ${ }^{1}$ The questionnaires were distributed to the human resources managers at these 291 companies or to other managers responsible for HRM in the company. The response rate was $38 \%$. It is important to stress that all the data given in this paper refer to the sample of businesses that have completed the questionnaire.

\section{Research results}

\section{a) Basic Human Resource Profile}

Of all the firms that participated in the survey, 62 are wholly-owned foreign companies, 35 are joint ventures, and either were originally joint ventures later changed into wholly-owned foreign companies. (Seven companies did not answer this question.) The majority of participants are companies with German investment (21/18.8\%), followed by Austrian (19/17\%) and American com

Table 1: Year of foundation of FDI-invested companies

\begin{tabular}{|c|c|c|}
\hline Year of foundation & Number of firms set up & Share on the total (\%) \\
\hline 1989 & 1 & 0.9 \\
\hline 1990 & 2 & 1.8 \\
\hline 1991 & 12 & 10.7 \\
\hline 1992 & 17 & 15.2 \\
\hline 1993 & 29 & 25.9 \\
\hline 1994 & 10 & 8.9 \\
\hline 1995 & 13 & 11.6 \\
\hline 1996 & 8 & 7.1 \\
\hline 1997 & 6 & 5.4 \\
\hline 1998 & 4 & 3.6 \\
\hline 1999 & 2 & 1.8 \\
\hline No answer & 8 & 7.1 \\
\hline
\end{tabular}

panies (15/13.4\%). French, Czech. and Dutch companies were also significant, with more than five companies each. One half were established in the time period 1989 - 1993, and the year 1993 alone accounted for the establishment of

\footnotetext{
${ }^{1}$ At the beginning of 1999 the average exchange rate was \$US $1=$ SK 40 (SK - Slovak crown)
} 
one-quarter of FDI-invested companies. In the years $1994-1999$, the other half were established (see Table 1).

The next question concerned the scale of financial investment in human resource management. Only twenty-eight companies from the sample were willing to answer this question. (see Table 2).

Table 2: Investment in human resources in FDI-invested companies (SK,000)

\begin{tabular}{|c|c|c|c|}
\hline Year & $\begin{array}{c}\text { Investment per year } \\
\text { total }\end{array}$ & $\begin{array}{c}\text { Investment per } \\
\text { employee }\end{array}$ & $\begin{array}{c}\text { Number of } \\
\text { companies } \\
\text { answering the } \\
\text { question }\end{array}$ \\
\hline 1991 & 29.7 & 0.4 & 1 \\
\hline 1992 & 745.5 & 10.5 & 3 \\
\hline 1993 & 749.3 & 19.0 & 6 \\
\hline 1994 & $23,506.2$ & 132.9 & 7 \\
\hline 1995 & $18,457.0$ & 140.3 & 20 \\
\hline 1996 & $20,898.7$ & 173.8 & 23 \\
\hline 1997 & $42,636.3$ & 270.1 & 28 \\
\hline 1998 & $99,406.0$ & 947.4 & \\
\hline
\end{tabular}

It is understable that investment has been growing because the number of companies has also increased. Interestingly, investment per capita has also been growing, which suggests a stronger emphasis on the development of human capital over time. In 1998 the average per capita investment in HR in 28 companies reached almost SK 1 million (US\$ 25,000). This amount is five times higher than the average yearly wage in these companies. According to the data provided, 28 companies invested SK 100 mil. (\$US 2.5 mil.) in the HR area alone. The ambition of the survey was to compare investment in buildings, equipment, and technology with the investment in HR. A direct comparison was not possible because of the limited number of companies who answered both questions. Despite this, the survey shows that investment in buildings, equipment, and technology is also rather high: one quarter of the sample each invested more than SK 100 million (US \$2.5 million) after their entry into Slovakia.

The companies were also asked if they had received some kind of support from state authorities (such as reimbursement of the expense of requalifying the local labor force, state subsidies for creating new job opportunities, etc.) for investing in human capital. Six companies received state support, 31 did not receive anything because there was no support available when they started their 
operations, and 18 companies simply gave up because of the bureaucratic procedures required for getting this support. Twenty-one companies have not yet applied state support for it but plan to do it in the future, and 34 companies did not answer this question. These results indicate that almost all companies in the sample relied on their own resources for investing in human resources.

Table 3: Investment in buildings, equipment and technology (SK mil.)

\begin{tabular}{|c|c|c|}
\hline Interval & Number of companies & Share of total (\%) \\
\hline $0-20$ & 9 & 8.0 \\
\hline $21-40$ & 10 & 8.9 \\
\hline $41-60$ & 6 & 5.4 \\
\hline $61-100$ & 7 & 6.2 \\
\hline $101-200$ & 9 & 8.0 \\
\hline $201-500$ & 11 & 9.8 \\
\hline $501-1000$ & 3 & 2.7 \\
\hline $1001-$ & 4 & 3.6 \\
\hline No answer & 53 & 47.3 \\
\hline
\end{tabular}

Table 4: Distribution of labor force according to age groups

\begin{tabular}{|c|c|c|c|c|c|c|}
\hline \multirow{2}{*}{$\begin{array}{l}\text { Age } \\
\text { interval }\end{array}$} & \multicolumn{2}{|c|}{ Employees } & \multicolumn{2}{|c|}{ Managers } & \multicolumn{2}{|c|}{ Workers } \\
\hline & $\begin{array}{l}\text { N. of } \\
\text { comp. }\end{array}$ & Share $(\%)$ & $\begin{array}{l}\text { N. of } \\
\text { comp. }\end{array}$ & Share $(\%)$ & $\begin{array}{l}\text { N. of } \\
\text { comp. }\end{array}$ & Share $(\%)$ \\
\hline $23-28$ & 11 & 9.8 & 3 & 2.7 & $19 *$ & 16.9 \\
\hline $29-34$ & 39 & 34.8 & 20 & 17.8 & 27 & 24.1 \\
\hline $35-40$ & 35 & 31.2 & 36 & 32.1 & 29 & 25.9 \\
\hline $41-46$ & 11 & 9.8 & 24 & 21.4 & 8 & 7.1 \\
\hline $47-$ & 0 & 0 & 8 & 7.1 & 2 & 1.8 \\
\hline $\begin{array}{c}\text { No } \\
\text { answer }\end{array}$ & 16 & 14.3 & 21 & 18.7 & 27 & 24.1 \\
\hline
\end{tabular}

* the first age interval in workers' category is 20 - 28 years

As for the average age of employees, the results are surprising. The average age of an employee in an FDI-invested company in Slovakia is 34.2 years; for managers, it is 38.4 , and for workers, it is 33.9 years. The distribution of the labor force by age appears below in Table 4. FDI-invested companies prefer to employ young people because they are more flexible, more willing to learn, 
speak foreign languages, and do not cling to customs inherited from the socialist period.

Approximately one half of the companies refused to provide their average pay. From the respondents, however, we can say that the average monthly pay of an employee in an FDI-invested company is SK 17,066 (about US \$427). Managers' average monthly salaries are SK 36,886 (about US \$922) and that of workers and other staff SK 14,768 (about US \$369). In Western terms, the labor force is very cheap, and FDI-invested companies can count on the fact that the wages they offer are usually much higher then those of local companies. The exact distribution of salaries and wages according to the data given by companies is shown in Table 5.

Table 5: Distribution of labor force according to wage categories

\begin{tabular}{|c|c|c|c|c|c|c|}
\hline \multirow{2}{*}{ Wage interval } & \multicolumn{2}{|l|}{ Employees } & \multicolumn{2}{l|}{ Managers } & \multicolumn{2}{l|}{ Workers } \\
\cline { 2 - 7 } & $\begin{array}{l}\text { N. of } \\
\text { comp. }\end{array}$ & $\begin{array}{l}\text { Share } \\
(\%)\end{array}$ & $\begin{array}{l}\text { N. of } \\
\text { comp. }\end{array}$ & $\begin{array}{l}\text { Share } \\
(\%)\end{array}$ & $\begin{array}{l}\text { N. of } \\
\text { comp. }\end{array}$ & $\begin{array}{l}\text { Share } \\
(\%)\end{array}$ \\
\hline $5,000-15,000$ & 32 & 28.6 & 3 & 2.7 & $26^{*}$ & 23.2 \\
\hline $15,001-25,000$ & 12 & 10.7 & 8 & 7.1 & 10 & 8.9 \\
\hline $25,001-35,000$ & 5 & 4.5 & 6 & 5.4 & 6 & 5.4 \\
\hline $35,001-45,000$ & 3 & 2.7 & 11 & 9.8 & 0 & 0 \\
\hline $45,001-55,000$ & 1 & 0.9 & 3 & 2.7 & 0 & 0 \\
\hline $55,001-65,000$ & 0 & 0 & 3 & 2.7 & 0 & 0 \\
\hline $65,001-$ & 0 & 0 & 2 & 1.8 & 0 & 0 \\
\hline No answer & 59 & 52.6 & 76 & 67.8 & 70 & 62.5 \\
\hline
\end{tabular}

* the first interval in workers category comprises the wages from SK 3,000

Approximately one half of FDI-invested companies are run by local managers, with the other half run by expatriates. Usually, only one expatriate is in the company (see Table 6). When we compare these results with the next question-"How many expatriates worked at your company at the time of its establishment?"--we find two interesting facts: 1) $40 \%$ per cent of companies started without expatriates and continue to not use them, and 2) the total number of expatriates in the entire sample went down over time from 215 to 114, in spite of overall growth in the number employees. The data suggest that (1) localization of management is an important part of human resource strategy for foreign companies in Slovakia, and (2) the firms have been able to find and attract capable local managers. 
Table 6 Number of expatriates in FDI - invested companies at date of entry and in 1999

\begin{tabular}{|c|c|c|c|c|}
\hline \multirow{2}{*}{$\begin{array}{l}\text { Number of } \\
\text { expatriates }\end{array}$} & \multicolumn{2}{|l|}{ At the entry } & \multicolumn{2}{|l|}{ In 1999} \\
\hline & $\begin{array}{l}\text { Number of } \\
\text { comp. }\end{array}$ & Share $(\%)$ & $\begin{array}{l}\text { Number of } \\
\text { comp }\end{array}$ & Share $(\%)$ \\
\hline 0 & 44 & 39.3 & 46 & 41.0 \\
\hline 1 & 27 & 24.1 & 35 & 31.2 \\
\hline 2 & 9 & 8.0 & 10 & 8.9 \\
\hline 3 & 8 & 7.1 & 4 & 3.6 \\
\hline 4 & 5 & 4.4 & 5 & 4.5 \\
\hline 5 & 2 & 1.8 & 1 & 0.9 \\
\hline 6 & 1 & 0.9 & 1 & 0.9 \\
\hline 7 & 1 & 0.9 & 0 & 0 \\
\hline 8 & 0 & 0 & 0 & 0 \\
\hline 9 & 0 & 0 & 0 & 0 \\
\hline 10 & 4 & 3.6 & 0 & 0 \\
\hline 11 & 1 & 0.9 & 0 & 0 \\
\hline 12 & 1 & 0.9 & 0 & 0 \\
\hline 16 & 0 & 0 & 1 & 0.9 \\
\hline 40 & 1 & 0.9 & 0 & 0 \\
\hline No answer & 8 & 7.1 & 9 & 8.0 \\
\hline
\end{tabular}

The next question ("How many local top managers left your company to work in other companies in Slovakia?") aims at the dispersion of management knowhow from FDI firms into the local economy. In 66 cases, none left the company, in 38 cases, one or two persons left the firm, and 8 firms did not answer the question. This result suggests that local top managers are satisfied with their jobs in foreign companies and that there is a low level of dispersion of new procedures into local companies.

According to the results of the next questions, Slovak top managers are rarely used for the posting abroad within multinationals. From 90 companies nobody was appointed for a post in another country within CEE, nor for any position in regional or corporate headquarters. Up to now 15 companies sent 27 managers to other subsidiaries in CEE and 35 managers from local companies were posted in regional or corporate headquarters. 


\section{b) Specific HRM issues in FDI-invested companies in Slovakia}

As visible from Table 7, the most important source of new managers was either through an acquisition or later internal recruiting within their own company. Technical personnel mostly came with the acquisition or directly from educational institutes or universities. Local workers usually came with the acquisition.

Table 7: Sources of local employees (Average value from rating on a scale of 1 to 5 , with 5 being the most important)

\begin{tabular}{|l|c|c|c|}
\hline & Managerial & Technical & Production \\
\hline Came with an acquisition & $\underline{\mathbf{3 . 3}}$ & $\underline{\mathbf{3 . 4}}$ & $\underline{\mathbf{3 . 9}}$ \\
\hline $\begin{array}{l}\text { Hiring from universities and } \\
\text { vocational/technical institutes }\end{array}$ & 2.8 & $\underline{\mathbf{3 . 4}}$ & 2.7 \\
\hline Hiring from local SOEs & $\mathbf{1 . 4}$ & 2.0 & 2.4 \\
\hline Hiring from local private firms & 2.3 & 2.7 & 2.9 \\
\hline Hiring from privatized firms & 1.9 & 2.4 & 2.4 \\
\hline $\begin{array}{l}\text { Hiring from other FDI-invested } \\
\text { companies }\end{array}$ & 2.8 & 2.6 & 2.1 \\
\hline $\begin{array}{l}\text { Hiring from foreign subsidiaries of } \\
\text { parent co. }\end{array}$ & 2.0 & $\mathbf{1 . 3}$ & $\mathbf{1 . 3}$ \\
\hline Internal recruiting & $\underline{\mathbf{3 . 3}}$ & 3.1 & 2.6 \\
\hline
\end{tabular}

Bold underlined - the highest figure, Italics - the lowest figure

As for the training of local managers, there is a visible shift from language training to functional training (see Table 8 below).

Table 8: Areas of training programs for local managers (Average value from rating on a scale of 1 to 5 , with 5 being the most important)

\begin{tabular}{|l|c|c|c|}
\hline Area & At the entry & Now & In the future \\
\hline General management & 3.7 & 3.7 & 3.8 \\
\hline Foreign language training & $\underline{\mathbf{4 . 4}}$ & 4.0 & 3.9 \\
\hline Corporate culture of MNC & 3.4 & 3.4 & 3.5 \\
\hline Functional training & 3.9 & $\underline{\mathbf{4 . 1}}$ & $\underline{\mathbf{4 . 2}}$ \\
\hline Technical training & 3.3 & 3.5 & 3.5 \\
\hline
\end{tabular}

Technical training and training in teamwork are the most important training goals for local workers (see Table 9 below). 
Table 9: Areas of training programs for local workers (Average value from rating on a scale of 1 to 5, with 5 being the most important)

\begin{tabular}{|l|c|c|c|}
\hline Area & At the entry & Now & In the future \\
\hline Technical training & $\underline{\mathbf{4 . 2}}$ & $\underline{\mathbf{4 . 1}}$ & $\underline{\mathbf{4 . 2}}$ \\
\hline Foreign language training & 3.0 & 3.0 & $\mathbf{3 . 0}$ \\
\hline Corporate culture of MNC & 2.9 & 2.9 & 3.1 \\
\hline Team work & 3.7 & 3.8 & $\underline{\mathbf{4 . 2}}$ \\
\hline Process improvement & 2.8 & 3.5 & 3.7 \\
\hline
\end{tabular}

As for sources of training, companies rely mostly on their own sources (in-house programs), followed by training provided in centralized corporate units. Universities, both local and Western, seem to be less important as training providers in comparison to consulting firms (Table 10).

Table 10: Providers of training for local employees (Average value from rating on a scale of 1 to 5 , with 5 being the most important)

\begin{tabular}{|l|c|c|c|}
\hline & At the entry & Now & In the future \\
\hline Local consulting firms & 3.1 & 3.4 & 2.6 \\
\hline $\begin{array}{l}\text { Western consulting firms } \\
\text { operating in CEE }\end{array}$ & 2.8 & 2.8 & 2.8 \\
\hline $\begin{array}{l}\text { Local universities or other } \\
\text { educational }\end{array}$ & 1.7 & 1.9 & 2.1 \\
\hline $\begin{array}{l}\text { Western universities operating in } \\
\text { CEE }\end{array}$ & $\mathbf{1 . 2}$ & $\mathbf{1 . 4}$ & $\mathbf{1 . 6}$ \\
\hline $\begin{array}{l}\text { Centralized in-house corporate } \\
\text { training unit }\end{array}$ & 3.5 & 3.7 & 3.6 \\
\hline Local in-house training & $\underline{\mathbf{3 . 9}}$ & $\underline{\mathbf{3 . 9}}$ & $\underline{\mathbf{4 . 1}}$ \\
\hline
\end{tabular}

Next question was aimed at the performance appraisal process in the managerial workforce. The most important criterion for top managers is financial results, in comparison with mid-level managers, who are subjected to regular performance reviews (Table 11). Coaching/development and 360-feedback are relatively less used in both categories. 
Table 11: Focus of performance management process for managerial workforce (Average value from rating on a scale of 1 to 5 , with 5 being the most important)

\begin{tabular}{|l|c|c|}
\hline & $\begin{array}{l}\text { Mid-level } \\
\text { management }\end{array}$ & Top management \\
\hline Regular performance review & $\underline{\mathbf{4 . 4}}$ & 4.3 \\
\hline Financial results & 4.0 & $\underline{\mathbf{4 . 5}}$ \\
\hline Leadership style & 3.5 & 3.7 \\
\hline Coaching and development & 3.0 & 3.2 \\
\hline Competency-based approach & 3.4 & 3.8 \\
\hline 360 feedback & 2.9 & 3.1 \\
\hline
\end{tabular}

The most common compensation practice in all categories is pay for performance, the least used practice is stock incentives. The results show that the best way to motivate the local labor force in all categories is a direct connection between performance and pay.

Table 12: Compensation practices applied in Slovakia (Average value from rating on a scale of 1 to 5 , with 5 being the most important)

\begin{tabular}{|l|c|c|c|}
\hline & Managerial & Technical & Production \\
\hline Pay for performance & $\underline{\mathbf{4 . 1}}$ & $\underline{\mathbf{4 . 2}}$ & $\underline{\mathbf{4 . 6}}$ \\
\hline Local profit sharing & 3.2 & 2.5 & 2.3 \\
\hline $\begin{array}{l}\text { Global/regional profit } \\
\text { sharing }\end{array}$ & 3.8 & 3.5 & 3.1 \\
\hline Individual bonus & 2.4 & 2.6 & 2.8 \\
\hline Stock incentives & 1.5 & 1.2 & 1.3 \\
\hline
\end{tabular}

Table 13 shows the ranking of problems in local companies with respect to managers, technicians and workers. In all categories, performance standards are an important issue - but less so in the manager's category, more so in the technicians' category, and most of all with respect to workers. In both the managerial and technical categories, however, finding qualified personnel is the most important problem. Retention of top staff, together with compensation issues, seem to be a little less important in comparison to finding and hiring the right people. In the workers' category, ethical issues, absenteeism, and "old behavior" are also important problems. Process improvement seems to be difficult for all categories. Legal disputes are the least important for all three categories of employees. 
Table 13: The most important HR challenges with respect to local employees (Average value on a scale of 1 to 5 , with 5 being the most important.)

\begin{tabular}{|l|c|c|c|}
\hline & Managerial & Technical & Production \\
\hline Performance standards & 2.6 & 2.9 & $\underline{3.2}$ \\
\hline Overcoming old work behavior & 1.8 & 2.3 & 2.9 \\
\hline Ethical issues & 1.5 & 1.7 & 2.4 \\
\hline Absenteeism & 1.4 & 1.5 & 2.1 \\
\hline Implementing team work & 1.8 & 2.2 & 2.1 \\
\hline Process improvement & 2.2 & 2.3 & 2.3 \\
\hline Finding qualified personnel & $\underline{3.1}$ & $\underline{3.2}$ & 2.7 \\
\hline Costs for finding qualified personnel & 2.3 & 2.2 & 1.9 \\
\hline Retention of top staff & 2.4 & 2.4 & 2.2 \\
\hline $\begin{array}{l}\text { Communication with expats in the } \\
\text { company }\end{array}$ & 1.8 & 1.7 & 2.0 \\
\hline Communication with HQ & 2.0 & 1.8 & 1.3 \\
\hline $\begin{array}{l}\text { Cultural differences (HQ vs. Slovak } \\
\text { empl.) }\end{array}$ & 1.7 & 1.9 & 2.0 \\
\hline Compensation - its level & 2.4 & 2.6 & 2.6 \\
\hline Compensation - its parts & 2.2 & 2.3 & 2.4 \\
\hline Union relations & 1.6 & 1.5 & 1.7 \\
\hline $\begin{array}{l}\text { Legal disputes, compliance with } \\
\text { local labor law }\end{array}$ & 1.1 & 1.1 & 1.2 \\
\hline
\end{tabular}

In the next part of the questionnaire, we asked about the strategies that companies use to address the most important human resources issues. The following strategies and approaches are the most common:

- thorough selection process, looking for top talent among young people, including co-operation with universities;

- appropriate financial motivation and compensation according to employee performance, premiums for good group performance and low absenteeism, etc.

additional financial benefits, including subsidies and bonuses for meals, commuting, holidays, and recreation; 
additional social benefits, including good working conditions, fitness centers, assistance with housing, providing apartments;

special benefits for managers (company car, mobile phone);

training and development (foreign language training and other training provided and paid by the company - team work, leadership, coaching, etc., and business trips to other foreign subsidiaries for benchmarking);

special stress on communication within the company (company's journals, meetings,

- Slovak language training for expatriates);

- special stress on implementing foreign parent's corporate culture and values;

- firing in the case of breaking rules.

- Impact of HRM know-how on local companies.

The assumption in this part of the survey is that it is very difficult--if not impossible--to measure the impact of new "Western" HRM practices on the change and restructuring of local companies. There was a survey question on the productivity before and after the entry of foreign investors, but only a very few companies from the sample were able or willing to provide these data. We must therefore rely on the opinion and qualitative judgment of human resource managers. They were asked the following questions with these results:

Table 14: Reply to the statement: Implementation of foreign know-how in HRM has meant a significant change in the methods which were used in HR area before the entry of foreign investor:

\begin{tabular}{|l|c|c|}
\hline & Number of answers & Share of answers (\%) \\
\hline Strongly agree & 17 & 15.2 \\
\hline Agree & 43 & 38.4 \\
\hline I do not know & 10 & 8.9 \\
\hline Disagree & 17 & 15.9 \\
\hline Strongly disagree & 1 & 0.9 \\
\hline No answer & 24 & 21.4 \\
\hline
\end{tabular}

More than one half of the responding companies acknowledge significant change in HRM after the entry of foreign investors. No answer was given by one fifth of the companies and another fifth of the companies disagree with the statement in the question. 
Table 15: Reply to the statement: In my opinion, this change has a positive impact on our company:

\begin{tabular}{|l|c|c|}
\hline & Number of answers & Share of answers (\%) \\
\hline Strongly agree & 21 & 18.8 \\
\hline Agree & 42 & 37.5 \\
\hline I do not know & 9 & 8.0 \\
\hline Disagree & 12 & 10.7 \\
\hline Strongly disagree & 0 & 0 \\
\hline No answer & 28 & 25.0 \\
\hline
\end{tabular}

Almost $57 \%$ of companies consider the change in HRM practice to be positive, one tenth to be negative, and one quarter did not answer the question.

Table 16: Reply to the statement: After the entry of foreign investors, new HRM know-how has positively influenced productivity in our company.

\begin{tabular}{|l|c|c|}
\hline & Number of answers & Share of answers (\%) \\
\hline Strongly agree & 8 & 7.1 \\
\hline Agree & 53 & 47.3 \\
\hline I do not know & 12 & 10.7 \\
\hline Disagree & 11 & 9.8 \\
\hline Strongly disagree & 0 & 0 \\
\hline No answer & 28 & 25 \\
\hline
\end{tabular}

More than half of all responding companies express the view that the new approach to HRM has resulted in an increase in productivity. One tenth disagree and a quarter of the companies did not answer this question.

A little less than one half of responding companies acknowledge the positive impact of HRM on productivity growth - five of them even think that HRM practices alone led to productivity growth in the company. One third of the companies estimate that HRM practices contribute to $25-50 \%$ of the productivity growth, $15 \%$ of companies give an even higher estimate in the range of $75-100 \%$.

The last questions in the survey are focused on the subordination of local HR managers and their communication with HQ and other subsidiaries. Nine percent of local human resource managers say they are directly managed by their regional $\mathrm{HQ}, 44 \%$ say that certain parts of the HR function are delegated to the 
local manager, and another is the responsibility of regional HQ. 36\% human resource managers have full responsibility for all local issues and $11 \%$ of companies did not replied.

Table 17: Reply to the question: What is the share of new HRM practices on the productivity growth in your company?

\begin{tabular}{|l|c|c|}
\hline & Number of answers & Share of answers (\%) \\
\hline None & 0 & 0 \\
\hline One quarter & 19 & 17.0 \\
\hline One half & 15 & 13.4 \\
\hline Three quarters & 12 & 10.7 \\
\hline $100 \%$ & 5 & 4.5 \\
\hline I do not know & 27 & 24.1 \\
\hline No answer & 34 & 30.3 \\
\hline
\end{tabular}

Communication between local and regional HR managers is considered to be very good in $35 \%$ of responding companies, sufficient in $42 \%$ of companies, and insufficient in 1\%. Eight percent of the responding companies consider communication with regional HQ as unnecessary. The rest of the companies did not reply. As for communication with the counterparts in other countries in CEE, $22 \%$ of human resource managers declare it as very good , $40 \%$ as sufficient, $10 \%$ as insufficient, and $10 \%$ as not necessary. The rest of companies did not answer this question.

\section{Correlation between productivity growth led by new HM methods and selected factors}

As the last step of the research, hypothesis tests were done to determine if there is a correlation between productivity growth in FDI-invested companies led by new HRM methods and other factors ${ }^{2}$, such as type of company, origin of foreign investor, major business of foreign investor, and number of expatriates at the beginning of company's operation. Statistical software Statgraphics was used to identify dependence, eventually independence of mentioned factors. Following hypotheses were analyzed:

$\mathrm{H} 0$ - There is no correlation between productivity growth led by new HRM methods in FDI-invested companies and type of company, such as joint venture,

\footnotetext{
${ }^{2}$ Following question was used for the assesment of productivity growth: New know-how of foreign parter in HRM reflected in productivity growth in our company: a) strongly agree, b) agree, c) I do not know, d) disagree, e) strongly disagree.
} 
wholly-owned company, or joint venture that changed into wholly-owned company.

The chi-square test performs a hypothesis test to determine whether or not to reject the idea that productivity and company type are independent. Since the Pvalue is less than 0.10 we can reject the hypothesis that productivity and type are independent at the 90\% confidence level. (Chi-square 11.71, P-value 0.0687). On the basis of frequency table we can state that $53.75 \%$ of all answers is concentrated in the type "joint venture" with "strongly agree" or "agree" as for the positive influence of new HR methods on productivity growth.

$\mathrm{H} 0$ - There is no correlation between productivity growth led by new HRM methods in FDI-invested companies and origin of company. (Fifteen countries were identified as countries of origin of investment, sixteenth group relates to multi-origin investment into one company).

The chi-square test performs a hypothesis test to determine whether or not to reject the idea that productivity and company origin are independent. Since the $\mathrm{P}$-value is greater than 0.10 we cannot reject the hypothesis that productivity and investment origin are independent. (Chi-square 51.26, P-value 0.2415). Therefore productivity may bear no relation to origin.

$\mathrm{H} 0$ - There is no correlation between productivity growth led by new HRM methods in FDI-invested companies and company business, such as production, commerce, services, and others (including combination of businesses).

The chi-square test performs a hypothesis test to determine whether or not to reject the idea that productivity and company business are independent. Since the P-value is greater than 0.10 we cannot reject the hypothesis that productivity and company business are independent. (Chi-square 18.88, P-value 0.7581). Therefore productivity may bear no relation to company business.

H 0 - There is no correlation between productivity growth led by new HRM methods in FDI-invested companies and number of expatriates working in company at the beginning of its operation.

The chi-square test performs a hypothesis test to determine whether or not to reject the idea that productivity and number of expatriates are independent. Since the P-value is greater than 0.10 we cannot reject the hypothesis that productivity and number of expatriates are independent. (Chi-square 22.52, Pvalue 0.8344 ). Therefore productivity may bear no relation to number of expatriates. The frequency table shows that almost one half - $47 \%$ of the total 81 observation - are cases of none or one expatriate in the company where HR manager strongly agreed or agreed that new HR methods had significant impact on productivity growth. 


\section{Conclusions}

The survey yielded some interesting, even paradoxical results: Slovakia as well as other CEE countries can boast about a well-educated labor force, but on the other hand, expenditures of FDI-invested companies on HR, including training and development, gradually grow over time. Another feature is high reliance on internal training and internal recruitment in these companies. Companies usually declare that one of their major problems in the HR area is to find the appropriate labor force, especially high-quality managers, but on the other hand, they have already started with their posting in other CEE or in regional or corporate headquarters, (although in limited number) which proves the quality of local management. High unemployment and low labor force mobility do not result in low turnover - companies ranked retention together with compensation as rather high among their "local HR problems." It is also interesting to see that ten years of transition have not been enough to change labor morale, especially among workers: companies still complain about old work behavior or ethical issues. On the other hand, despite a long union tradition, "the union problem" is not ranked among the most important issues.

The overview of "HR problems" (Table 13) indicates one important conclusion: no problem is ranked too high, because the most important problems were ranked only at the value of about 3 from a five-point scale. We can conclude that companies are generally satisfied with the labor force and even on a special role of labor force in transition of companies.

According to the experience of more than half of all HR managers in FDIinvested companies in Slovakia, the new approach to HRM implemented by foreign investors has raised the productivity of their company. One third of the companies estimate that HRM practices account for $25-50 \%$ of their productivity growth, $15 \%$ of the companies give an even higher estimate in the range of $75-100 \%$, and $5 \%$ of them even think that the appropriate HRM practices alone led to the total productivity growth in the company. These results show that human capital handled and motivated in the right way can be a significant if not the decisive factor for change in local companies.

Correlation analysis showed that there is the correlation between productivity growth led by new HRM practices and type of company. The highest frequency of positive answers on productivity growth was found in joint venture as a company type. The reason could be that the entry of foreign investor into local company was usually followed by his effort to increase the original low productivity by implementing corporate culture, training, development and adequate compensation and benefits. This effect was most visible just in joint ventures where there is relatively easier to compare the former and the current productivity. 
Surprisingly, no correlation was found between productivity growth and origin of foreign investors. It could be explained by the fact that all countries of origin in the sample except for two are developed Western countries. The assumption is that the companies from these countries have been operating in market conditions for many years and all of them have implemented more effective methods in HR area in comparison to local, formerly state-owned companies. Therefore there is no special difference in the origin of investment and its impact on productivity growth.

No correlation was found between productivity growth and company business. The foreign practices in HRM had mostly positive impact on productivity growth, no matter whether in production, commerce or services. As soon as foreign investor enters a company, he implements HR procedures which were not typically used neither in local production, nor commerce nor services and that's why they mostly prove efficient.

The last hypothesis test was done for correlation between productivity growth and number of expatriates. Surprisingly, there is no correlation between these two factors. It means local managers and labor force do not necessarily need the presence of expatriates in companies. What they need are methods and knowhow, simply to know and learn how to lead, stimulate and evaluate people. The results suggest that it could be done through training of local managers rather than through presence of expatriates in companies.

Generally, according to the experience of FDI-invested companies, three factors are of major importance for involving people in the management of their own companies and changing them from a passive audience into drivers for change:

1) implementation of modern HRM practices;

2) investments in training and development of the local labor force;

3) appropriate financial compensation, with motivational tools primarily based on results and performance.

Based on the results of the survey, there are some important lessons for local companies with no foreign capital involvement:

1) it is not possible to expect the dispersion of HRM know-how through the movement of managers, since they are usually satisfied with their posting in FDI-invested companies;

2) it is possible to learn from the experience of FDI-invested companies through professional forums and personal contacts at little or no cost;

3 ) it is possible, although not easy, to implement to a certain extent the motivational tools used in FDI-invested companies;

4) it is not yet possible to follow the compensation practices of FDI-invested companies and their major investment in training and development; 
5) while compensation levels depend on the performance of the company, the amount for training and development should be shared by companies and the state through state subsidies and the utilization of state institutions (technical institutes, universities).

\section{References}

Balaz, P. (1999) Priprava manazerov v trhovych ekonomikach Ekonomicke rozhlady, Vol. 28 , N. 3, p. $238-249$

Business Central Europe (1999) A survey of IT skills, November: pp. 45 - 52

Dowling, P.J. et alt. (1994) International Dimensions of Human resource management, $2^{\text {nd }}$ edition, Belmont: Wadsworth Publishing Company

Ferencikova, S. (1998) Foreign Direct Investment as Factor of Change in Transition Economy Ekonomicke rozhlady, Vol. 27, N. 3, p. 229 - 245

Fogel, D.S. (ed.) (1995) Firm Behavior in Emerging Market Economies Brookfield: Ashgate Publishing Company von Eckardstein, D. et alt. (1999) Management: Theorien Fuhrung - Veranderung, Stuttgart: Schaffer-Poeschel

Kita, J. et alt. (1999) Restrukturalizacia slovenskych podnikov v podmienkach medzinarodnej integracie, Bratislava: EU

Oddou, G. and Mendelhall. M. (1998) Cases in International Organizational Behavior Blackwell Publishers

Sakova, B. (1998) Transnacionalne korporacie a ekonomicky rast, Bratislava: Sprint

Springer, R. (1995) Market Entry and Marketing Strategies for Eastern Europe, Journal of East-West Business, Vol. 1, No. 3, p. 67 - 104

Springer, R. (1997) Osteuropamarketing - Umfeld, Instrumente, Strategien. Wien: WU

Springer, R., Chadraba, P. ed. (1998) Proceedings of the $6^{\text {th }}$ Annual Conference on Marketing Strategies for Central and Eastern Europe Vienna: Wirtschaftsuniversitat

Szarkova, M. (1998) Psychologia pre manazersku prax Bratislava: Karprint

World Competitiveness Yearbook (1998) IMD Lausanne

World Development Report (1996) From Plan to Market Oxford: Oxford University Press

Zorkociova, O. (1999) Vplyv transformacneho procesu ekonomickych systemov statov strednej Europy na zmeny v oblasti vonkajsich ekonomickych vztahov Ekonomicke rozhlady, Vol. 28, N. 3, p. $265-272$ 